\title{
Short communication: Identification of subclinical cow mastitis pathogens in milk by matrix-assisted laser desorption/ionization time-of-flight mass spectrometry
}

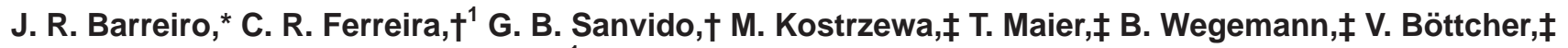 \\ M. N. Eberlin, $\dagger$ and M. V. dos Santos ${ }^{\star 1}$ \\ *University of São Paulo, School of Veterinary Medicine and Animal Science, Pirassununga 13635-900, Brazil \\ †ThoMSon Mass Spectrometry Laboratory, Institute of Chemistry, University of Campinas-UNICAMP Campinas 13083-970, São Paulo, Brazil \\ ‡Bruker Daltonik GmbH, Bremen D-28359, Germany
}

\begin{abstract}
Subclinical mastitis is a common and easily disseminated disease in dairy herds. Its routine diagnosis via bacterial culture and biochemical identification is a difficult and time-consuming process. In this work, we show that matrix-assisted laser desorption/ionization time-of-flight mass spectrometry (MALDI-TOF MS) allows bacterial identification with high confidence and speed (1 d for bacterial growth and analysis). With the use of MALDI-TOF MS, 33 bacterial culture isolates from milk of different dairy cows from several farms were analyzed, and the results were compared with those obtained by classical biochemical methods. This proof-of-concept case demonstrates the reliability of MALDI-TOF MS bacterial identification, and its increased selectivity as illustrated by the additional identification of coagulase-negative Staphylococcus species and mixed bacterial cultures. Matrix-assisted laser desorption-ionization mass spectrometry considerably accelerates the diagnosis of mastitis pathogens, especially in cases of subclinical mastitis. More immediate and efficient animal management strategies for mastitis and milk quality control in the dairy industry can therefore be applied.

Key words: bacteria identification, matrix-assisted laser desorption/ionization time-of-flight mass spectrometry (MALDI-TOF MS), subclinical mastitis diagnosis
\end{abstract}

Subclinical mastitis, an udder infection without clinical signs that is commonly encountered in cows, is a major problem in the dairy industry. The disease af-

Received July 9, 2010.

Accepted August 31, 2010.

${ }^{1}$ Corresponding authors: mveiga@usp.br and christina@iqm. unicamp.br fects both milk quality and yield, and may lead to rapid transmission of the infection to healthy cows in the herd. Microbiological methods routinely used to diagnose subclinical mastitis are based on changes in milk composition caused by bacterial growth and enzymatic and immunological reactions in the infected dairy cows (Peeler et al., 2003; Santos et al., 2004).

Many microorganisms have been identified as agents of mastitis infection. In Germany, for instance, 5 bacterial species (Staphylococcus aureus, Corynebacterium spp., Streptococcus uberis, Streptococcus dysgalactiae, and Escherichia coli) have been shown responsible for the majority (approximately 80\%) of cases (Barkema et al., 1998). In Brazil, a recent survey showed that the 3 major pathogens causing mastitis are Corynebacterium spp., Staphylococcus spp., and Streptococcus spp. (Souto et al., 2010).

Routine microbiological methods applied to microorganism identification have remained nearly unchanged over the last century. These methods still employ classical approaches based on sample streaking, colony growth using various culture media, and morphological and biochemical characterization of the isolated bacterial species. On average, routine milk microbiological procedures take from 5 to $8 \mathrm{~d}$ to be completed and require the use of various biochemical tests and the evaluation of experts (NMC, 1999).

Recently, bacterial identification at the molecular level has been investigated using matrix-assisted laser desorption/ionization time-of-flight mass spectrometry (MALDI-TOF MS; Fenselau and Demirev, 2001). Many microorganisms have been identified by MALDITOF MS via characteristic "chemical signatures" in a high-throughput fashion using straightforward extraction and sample work-up protocols. After initial bacterial growth that requires $1 \mathrm{~d}$ on average, and using crude bacterial extracts or lysate supernatants of whole cells, bacterial determination has been performed by MALDI-TOF MS in a few minutes (Holland et al., 1996, 
Mellmann et al., 2008). This technique has therefore revolutionized the field of bacterial screening by providing a much faster, more reliable, and highly sensitive technique for bacteria identification. These features are particularly attractive for bacterial isolates screening in contaminated milk at subclinical levels.

Matrix-assisted laser desorption/ionization is a "soft" ionization technique that allows for the detection of intact molecular species from pure compounds or complex mixtures. Matrix-assisted laser desorption/ionization time-of-flight MS of bacteria identifies protein "fingerprints," a group of mainly ribosomal proteins unique to each bacterial species (Ieven et al., 1995; Claydon et al., 1996; Keys et al., 2004; Carbonnelle et al., 2007; Barbuddhe et al., 2008). Matrix-assisted laser desorption/ionization time-of-flight MS bacterial identification has also shown high interlaboratory reproducibility (Mellmann et al., 2009), and is rapidly being incorporated into human clinical microbiological routines. This technique requires little MS expertise, the use of simple instruments, and relatively fast operator training. When compared with DNA analysisbased technologies, MALDI-TOF MS requires smaller amounts of biological material and involves simpler sample preparation protocols with no initial assessment, such as Gram staining, (Fenselau and Demirev, 2001; Ilina et al., 2009; Mellmann et al., 2009; Ilina et al., 2010).

In this work, we tested the applicability of MALDITOF MS for bacterial screening of subclinical mastitis in cows. Clinical samples of 33 bacterial strains isolated from samples of milk were collected from dairy cows on various farms in São Paulo State, Brazil. For comparison, these bacterial strains were also submitted to classical routine biochemical identification testing.

To isolate bacteria from milk samples, $10 \mu \mathrm{L}$ of sampled milk was streaked onto blood agar plates and incubated at $37^{\circ} \mathrm{C}$ for $24 \mathrm{~h}$ to allow for bacterial growth. The biochemical identification of the species was performed by means of catalase production, coagulase test, spore staining, and (for some samples) Gram staining.

To prepare the samples for MALDI-TOF MS, the bacterial strains isolated from milk were thawed and cultured for $24 \mathrm{~h}$ in a brain heart infusion broth. The bacterial culture was centrifuged, inactivated in $75 \%$ ethanol, and submitted to bacterial extraction, which was performed as detailed in the literature (Barbuddhe et al., 2008; Lartigue et al., 2009; Ilina et al., 2010). By this protocol, the microtube containing isolated bacteria in $75 \%$ ethanol solution was centrifuged (all centrifugation steps were at $13,000 \times g$ for $2 \mathrm{~min}$ ), and the supernatant was removed by carefully pouring it from the microtube. A second centrifugation step was performed and the remaining liquid was carefully re- moved with a pipette tip. Bacterial pellets were allowed to air dry at room temperature for 5 to $10 \mathrm{~min}$. A solution of $70 \%$ formic acid was added to lyse bacterial cells and to release the inner-cell proteins, predominantly the ribosomal proteins that produce diagnostic ions in MALDI fingerprinting (Ryzhov and Fenselau, 2001). The $70 \%$ formic acid solution was added proportionally to the size of pellet to completely dissolve it. Subsequently, $100 \%$ acetonitrile was added to each sample in volumes equal to the $70 \%$ formic acid solution added, thus producing a bacterial extract in a 1:1 ratio of $70 \%$ formic acid and acetonitrile. A final centrifugation step was performed to separate bacterial cell debris from the supernatant containing the inner-cell proteins used for the MALDI-TOF MS identification.

To prepare the MALDI target plates, $1 \mu \mathrm{L}$ of bacterial extract was placed onto a steel target plate (MSP 96 polished-steel target; Bruker Daltonik, Bremen, Germany) and allowed to air dry. The dried supernatant, overlaid with $1 \mu \mathrm{L}$ of matrix solution, consisted of $\alpha$-cyano-4-hydroxy-cinnamic acid diluted in 50\% acetonitrile and $2.5 \%$ trifluoroacetic acid. The MALDITOF MS was performed in a Bruker Microflex LT MALDI-TOF mass spectrometer operated in the linear mode and equipped with a 337-nm nitrogen laser using FlexControl 3.3 software (Bruker Daltonik). The mass spectra were collected within the mass range of 2,000 to $20,000 \mathrm{~m} / z$. Two hundred forty laser shots were accumulated to generate each spectrum. Spectra were analyzed with MALDI Biotyper 2.0 software (Bruker Daltonik) at default settings. For each sample, the automatic analysis generated a peak list, which was used to match a reference library by the integrated patternmatching algorithm. The result was given by means of a $\log$ score with a maximum value of 3.0. Score values higher than 1.7 were considered reliable for genus identification, and scores higher than 2.0 were considered probable for species identification. In this study, only scores higher than 2.0 were considered. In general, the MALDI Biotyper pattern-matching algorithm considers the matches of the unknown sample spectrum against the reference database and the reverse matches of the main spectrum with the unknown spectrum; it also compares the relative intensities of unknown and database spectra (Lartigue et al., 2009).

Table 1 summarizes the results of biochemical and MALDI-TOF MS characterization of the 33 samples studied. The isolated bacteria were identified by classical microbiological routine protocols as Staph. aureus $(\mathrm{n}=13)$, Strep. agalactiae $(\mathrm{n}=10)$ or CNS $(\mathrm{n}=10)$. Samples displaying divergent results for each identification technique used were sent for $16 \mathrm{~S}$ rRNA gene sequencing for a more reliable identification. Figure 1 presents a comparison of the analysis workflow of 
Table 1. Biochemical identification and matrix-assisted laser desorption/ionization-time-of-flight mass spectrometry (MALDI-TOF MS) identification of bacterial strains isolated from different milk samples from cows presenting subclinical mastitis

\begin{tabular}{lll}
\hline $\begin{array}{l}\text { Samples, } \\
\mathrm{n}\end{array}$ & $\begin{array}{l}\text { Biochemical } \\
\text { identification }\end{array}$ & MALDI-TOF MS \\
\hline 11 & Staphylococcus aureus & Staph. aureus \\
1 & Staph. aureus & Staph. haemolyticus \\
1 & Staph. aureus & Enterococcus faecalis/Staph. aureus ${ }^{2}$ \\
10 & Streptococcus agalactiae & Strep. agalactiae \\
1 & CNS & Staph. simulans \\
2 & CNS & Staph. aureus \\
5 & CNS & Staph. epidermidis $^{1}$ \\
1 & CNS & Staph. chromogenes $^{1}$ \\
1 & CNS & Staph. haemolyticus \\
\hline
\end{tabular}

${ }^{1}$ The $16 \mathrm{~S}$ ribosomal RNA sequencing result matched the MALDI-TOF MS identification.

${ }^{2}$ Algorithm-detected mixed bacterial culture.

routine microorganism biochemical identification and MALDI-TOF MS.

The MALDI-TOF MS and biochemical identifications were performed for all 13 Staph. aureus samples. Each sample was cultured twice and similar results were observed. Eleven out of 13 bacterial isolates presented the same results through both identification methods. All Strep. agalactiae samples yielded the same results for both biochemical and MALDI-TOF MS identification procedures. Superposed spectra of Strep. agalactiae (Figure 2, in red, from the Biotyper database) present the same ions observed in the investigated samples (Figure 2, in light blue). From the data shown in Figure 2 , it is clear that MALDI-TOF MS (based on conserved protein profiles) provides characteristic protein profiles that allow for identification of different species from the same bacterial genus (i.e., Strep. agalactiae and Strep. dysgalactiae). The MALDI Biotyper Database comprises data from strain collections (e.g., American Type Culture Collection, ATCC) and sequenced bacterial strains, and has been optimized for Strep. agalactiae identification (Lartigue et al., 2009).

To confirm some identification results provided by MALDI-TOF MS as compared with the classical microbiology results (Table 1), the 16S rRNA gene of certain samples was sequenced (see Table 1). One sample was identified as Staph. aureus by the biochemical procedures previously mentioned, whereas the samples identified by MALDI-TOF MS were identified as a Staph. haemolyticus (compare with Figure 3, for Staph. aureus and Staph. haemolyticus, respectively). The $16 \mathrm{~S}$ rRNA gene sequencing confirmed the MALDI-TOF MS identification as Staph. haemolyticus. Matrix-assisted laser desorption/ionization-MS is also able to identify mixed bacterial cultures, as exemplified by 1 of the samples identified as Staph. aureus by biochemical testing. The MALDI-TOF MS displayed a protein signature corresponding to a mixture of Enterococcus faecalis and
Staph. aureus (Table 1). This mixed bacterial culture may explain the positive coagulase reaction of this isolate.

Many coagulase-negative Staphylococcus species are classified as coagulase-negative and are commonly involved in mastitis infections. Routinely, CNS species are not further determined by biochemical procedures, but further identification was achieved by MALDI-TOF MS (Figure 4; Dubois et al., 2010). The coagulase-negative Staph. aureus was not expected, although Staph. aureus strains displaying negative reaction in the coagulase tube test do exist (Mlynarczyk et al., 1998). Similarly, the presence of coagulase-negative Staph. aureus has been reported in 1 out of 26 Staph. chromogens (a coagulase-negative Staphylococcus) isolated from 44 subclinical mastitis isolates from dairy herds in Belgium. The 1 isolate identified as a Staph. aureus strain by molecular characterization via transfer RNA intergenic spacer PCR failed to be identified microbiologically as it showed no positive coagulase reaction (Catry et al., 2003). Note that characteristic MALDI-TOF MS of CNS were obtained from coagulase-negative species, such as Staph. simulans, Staph. epidermidis, and Staph. chromogens. This information, easily obtained by MALDI-TOF MS, is important for a better characterization of pathogens causing mastitis in cows and increases the prospective applications of this technique in dairy science.

Four ATCC strains were also cultured and submitted to MALDI Biotyper identification: Enterococcus faecalis ATCC 29212, Pseudomonas aeruginosa ATCC 27853, Staph. aureus ATCC 29213, and Escherichia coli ATCC 25922. Because these ATCC strains also were present in the MALDI Biotyper 2.0 database, these strains could be identified unequivocally (data not shown).

The 16S rRNA gene polymorphism is widely accepted as the "gold standard" for bacteria identification with ambiguous biochemical profiles (Relman et al., 1990, 

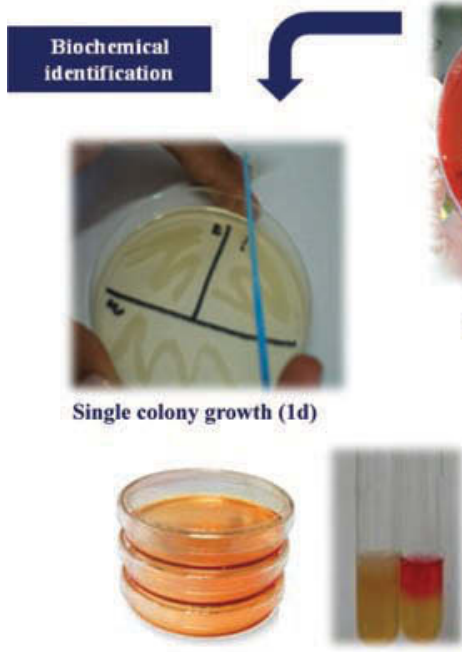

Biochemical testing ( 3 to $6 \mathrm{~d})$

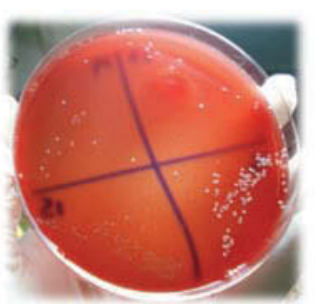

Bacterial growth (1d)

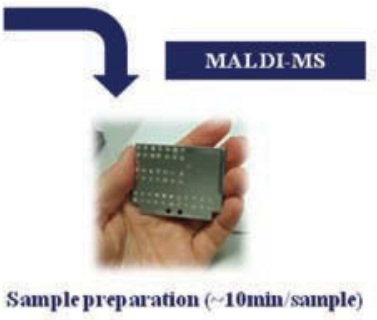

Sample preparation ( $10 \mathrm{~min} /$ sample)

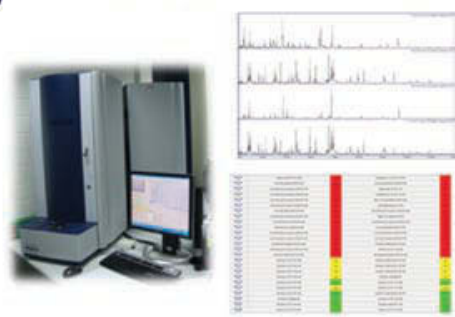

MALDI-TOF spectra acquisition and datab ankprocessing ( $\sim 2 \mathrm{~min} /$ sample $)$

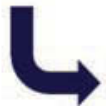

5 to $8 \mathrm{~d}$

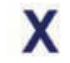

Id

Figure 1. Schematics comparing the workflow of classical routine microorganism biochemical identification and the workflow normally used in matrix-assisted laser desorption/ionization-time-of-flight mass spectrometry (MALDI-TOF MS) for clinical isolates identification. After initial growth of the microorganism (for $24 \mathrm{~h}$ after sample streaking), microorganism identification is performed in a few minutes by MALDI-TOF MS compared with 5 to $7 \mathrm{~d}$ for the classical biochemical methodologies. High-throughput MALDI-TOF MS can also be performed for 96 or 384 samples on each target plate.
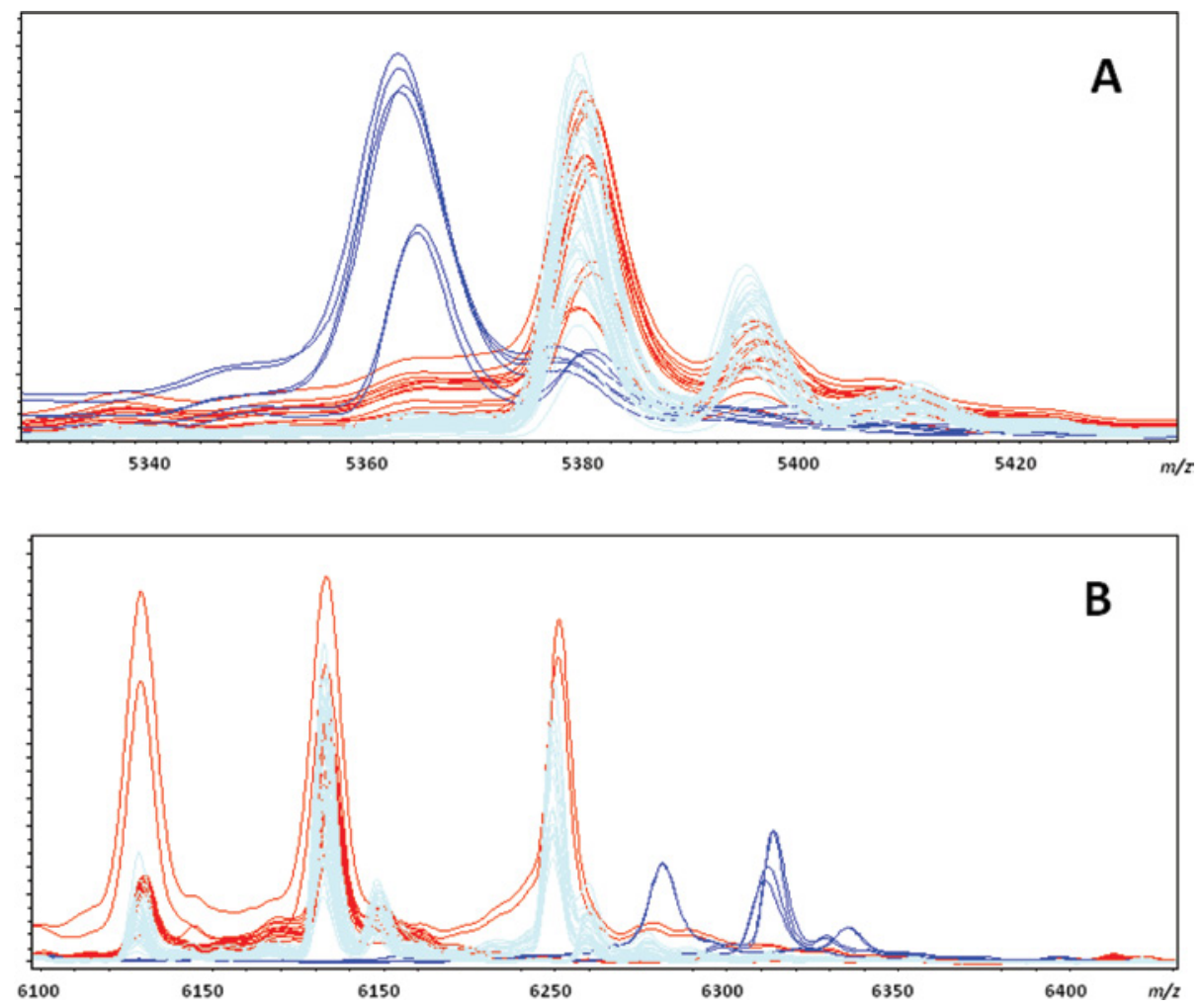

Figure 2. Matrix-assisted laser desorption/ionization-time-of-flight mass spectrometry at the ranges of (A) 5,300 to $5,450 \mathrm{~m} / z$ and (B) 6,100 to $6,500 \mathrm{~m} / z$ from reference spectra of Streptococcus agalactiae (red lines), reference spectra of Streptococcus dysgalactiae (dark blue lines), and the spectra obtained Strep. agalactiae samples (light blue lines). Note that the 10 Strep. agalactiae samples are clearly matched with the Strep. agalactiae from the reference spectra. 


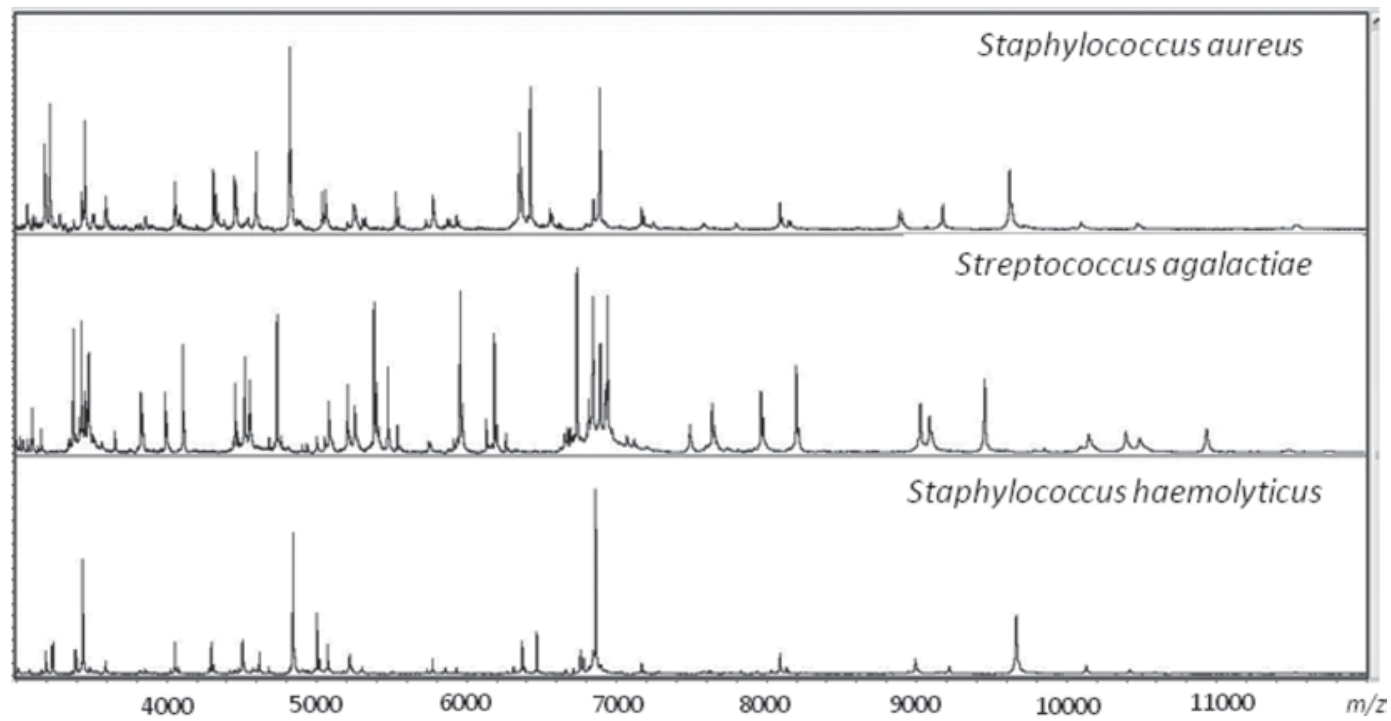

Figure 3. Matrix-assisted laser desorption/ionization-time-of-flight mass spectrometry of 3 bacterial isolates. Note the characteristic protein profiles obtained for Staphylococcus aureus, Streptococcus agalactiae, and Staphylococcus haemolyticus.

1992). It is highly conserved within species and among species of the same genus; therefore, this method usually provides more accurate and faster results compared with conventional biochemical protocols (Ferroni et al., 2002; Becker et al., 2004; Cloud et al., 2004).
Some unexpected results presented in this work are related to the different methods of bacterial strain identification used in the classical biochemical procedures (colony morphology, staining, and enzymatic reactions) compared with the MALDI-TOF MS approach, which

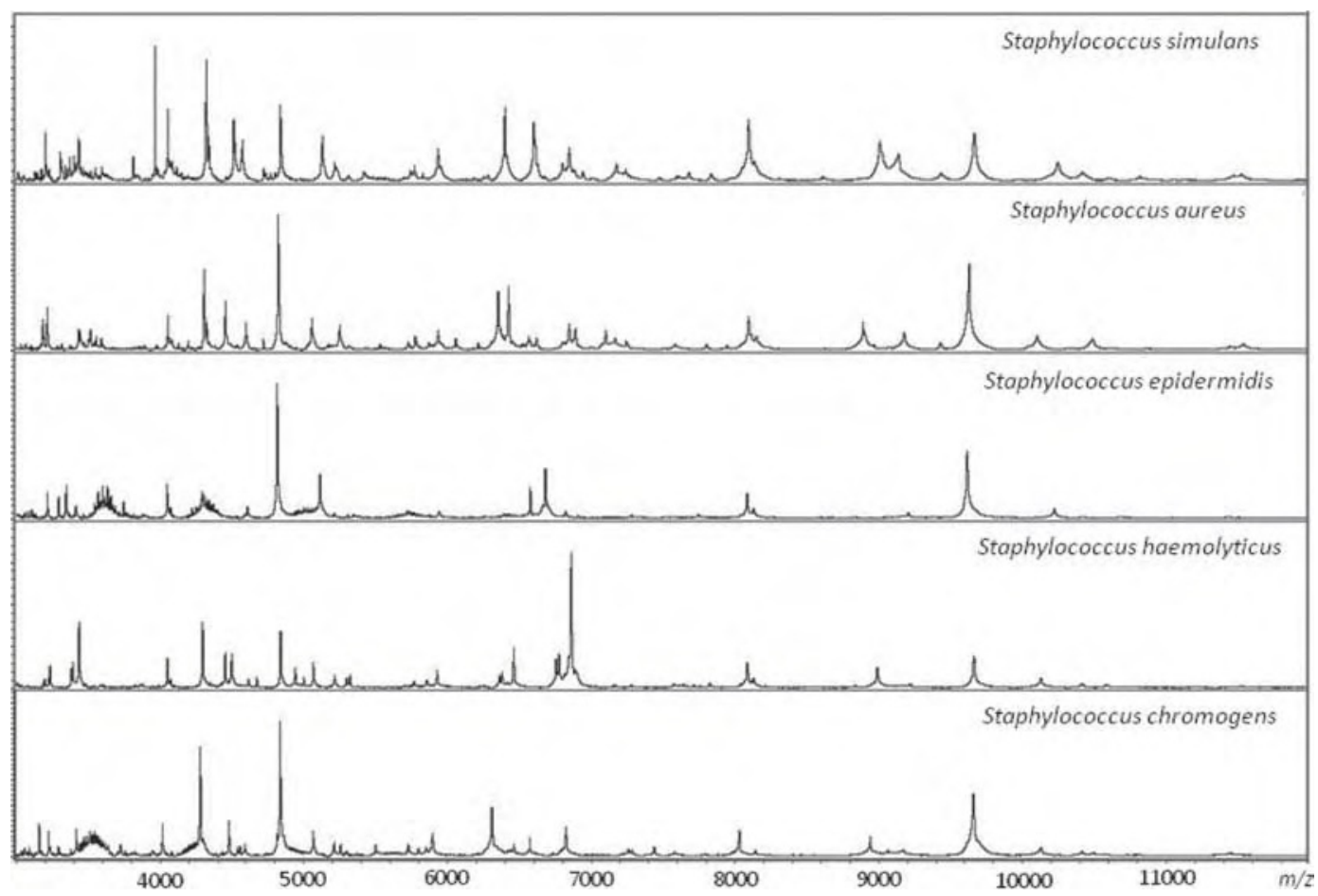

Figure 4. Matrix-assisted laser desorption/ionization (MALDI)-time-of-flight mass spectrometry CNS isolates. Note the identification of CNS isolates. These profiles have been readily related to a bacterial genus and species by data treatment with the MALDI Biotyper Database. 
is based on chemical signatures provided by protein profiles. The classical biochemical procedures for bacteria identification are more susceptible to incorrect human evaluation or errors during sample work-up, as indicated by the identification of Strep. uberis isolated from cow mastitis samples (Odierno et al., 2006). Approaches at the molecular level have long been recognized as important tools in microbiology (Kolbert and Persing, 1999), and MALDI-TOF MS employing "molecular fingerprints" seems to provide a reliable tool for microorganism identification. This seems to open a new era in microbiology screening in which conventional phenotypic methods will shift to molecular methods capable of providing faster and more accurate responses and similar genome-related methods of taxonomic and phylogenetic analysis.

The results presented herein, supported by similar and extensive data for clinical human microbiology (Barbuddhe et al., 2008; Mellmann et al., 2008, 2009; Sauer et al., 2008; Ilina et al., 2009; Lartigue et al., 2009; Marklein et al., 2009; Nagy et al., 2009; Dubois et al., 2010; Ilina et al., 2010; Seibold et al. 2010), show that MALDI-TOF MS provides faster detection (1 d vs. 5-8 d) and therefore the possibility of an earlier treatment of subclinical and clinical mastitis with appropriate antibiotics. In the dairy industry, MALDITOF MS can also provide a faster, cheaper, and more reliable identification of microorganisms for a more comprehensive microbiological quality control of milk.

\section{ACKNOWLEDGMENTS}

We are grateful to Simone Stumpf and Thomas Wenzel (both of Bruker Daltonik GmbH, Bremen, Germany) for their collaboration in this work, to Carol H. Collins (University of Campinas, Campinas, SP, Brazil) and Beatrice Razzo (University of Pennsylvania, PA) for English review, and to the Brazilian National Council for Scientific and Technological Development (CNPq, Brasilia, DF, Brazil) and the São Paulo State Science Foundation (FAPESP, Sao Paulo, SP, Brazil) for funding.

\section{REFERENCES}

Barbuddhe, S. B., T. Maier, G. Schwarz, M. Kostrzewa, H. Hof, E. Domann, T. Chakraborty, and T. Hain. 2008. Rapid identification and typing of listeria species by matrix-assisted laser desorption ionization-time of flight mass spectrometry. Appl. Environ. Microbiol. 74:5402-5407.

Barkema, H. W., Y. H. Schukken, T. J. Lam, M. L. Beiboer, H. Wilmink, G. Benedictus, and A. Brand. 1998. Incidence of clinical mastitis in dairy herds grouped in three categories by bulk milk somatic cell counts. J. Dairy Sci. 81:411-419.

Becker, K., D. Harmsen, A. Mellmann, C. Meier, P. Schumann, G. Peters, and C. von Eiff. 2004. Development and evaluation of a quality-controlled ribosomal sequence database for $16 \mathrm{~S}$ ribosomal
DNA-based identification of Staphylococcus species. J. Clin. Microbiol. 42:4988-4995.

Carbonnelle, E., J. L. Beretti, S. Cottyn, G. Quesne, P. Berche, X. Nassif, and A. Ferroni. 2007. Rapid identification of staphylococci isolated in clinical microbiology laboratories by matrix-assisted laser desorption ionization-time of flight mass spectrometry. J. Clin. Microbiol. 45:2156-2161.

Catry, B., L. A. Devriese, H. Laevens, S. De Vliegher, M. Vaneechoutte, G. Opsomer, and A. de Kruif. 2003. Antibiotic susceptibility and resistance of Staphylococcus chromogenes from bovine mastitis. Acta Vet. Scand. 44(Suppl. 1):89.

Claydon, M. A., S. N. Davey, V. Edwards-Jones, and D. B. Gordon. 1996. The rapid identification of intact microorganisms using mass spectrometry. Nat. Biotechnol. 14:1584-1586.

Cloud, J. L., P. S. Conville, A. Croft, D. Harmsen, F. G. Witebsky, and K. C. Carroll. 2004. Evaluation of partial 16S ribosomal DNA sequencing for identification of nocardia species by using the MicroSeq 500 system with an expanded database. J. Clin. Microbiol. 42:578-584.

Dubois, D., D. Leyssene, J. P. Chacornac, M. Kostrzewa, P. O. Schmit, R. Talon, R. Bonnet, and J. Delmas. 2010. Identification of a variety of Staphylococcus species by matrix-assisted laser desorption ionization-time of flight mass spectrometry . J. Clin. Microbiol. 48:941-945.

Fenselau, C., and P. A. Demirev. 2001. Characterization of intact microorganisms by MALDI mass spectrometry. Mass Spectrom. Rev. 20:157-171.

Ferroni, A., I. Sermet-Gaudelus, E. Abachin, G. Quesne, G. Lenoir, P. Berche, and J. L. Gaillard. 2002. Use of $16 \mathrm{~S}$ rRNA gene sequencing for identification of nonfermenting gram-negative bacilli recovered from patients attending a single cystic fibrosis center. J. Clin. Microbiol. 40:3793-3797.

Holland, R. D., J. G. Wilkes, F. Rafii, J. B. Sutherland, C. C. Persons, K. J. Voorhees, and J. O. Lay, Jr.. 1996. Rapid identification of intact whole bacteria based on spectral patterns using matrixassisted laser desorption/ionization with time-of-flight mass spectrometry. Rapid Commun. Mass Spectrom. 10:1227-1232.

Ieven, M., J. Verhoeven, S. R. Pattyn, and H. Goossens. 1995. Rapid and economical method for species identification of clinically significant coagulase-negative Staphylococci. J. Clin. Microbiol. 33:1060-1063.

Ilina, E. N., A. D. Borovskaya, M. M. Malakhova, V. A. Vereshchagin, A. A. Kubanova, A. N. Kruglov, T. S. Svistunova, A. O. Gazarian, T. Maier, M. Kostrzewa, and V. M. Govorun. 2009. Direct bacterial profiling by matrix-assisted laser desorption-ionization time-of-flight mass spectrometry for identification of pathogenic Neisseria. J. Mol. Diagn. 11:75-86.

Ilina, E. N., A. D. Borovskaya, M. V. Serebryakova, V. V. Chelysheva, K. T. Momynaliev, T. Maier, M. Kostrzewa, and V. M. Govorun. 2010. Application of matrix-assisted laser desorption/ionization time-of-flight mass spectrometry for the study of Helicobacter pylori. Rapid Commun. Mass Spectrom. 24:328-334.

Keys, C. J., D. J. Dare, H. Sutton, G. Wells, M. Lunt, T. McKenna, M. McDowall, and H. N. Shah. 2004. Compilation of a MALDITOF mass spectral database for the rapid screening and characterisation of bacteria implicated in human infectious diseases. Infect. Genet. Evol. 4:221-242.

Kolbert, C. P., and D. H. Persing. 1999. Ribosomal DNA sequencing as a tool for identification of bacterial pathogens. Curr. Opin. Microbiol. 2:299-305.

Lartigue, M. F., G. Hery-Arnaud, E. Haguenoer, A. S. Domelier, P. O. Schmit, N. van der Mee-Marquet, P. Lanotte, L. Mereghetti, M. Kostrzewa, and R. Quentin. 2009. Identification of Streptococcus agalactiae isolates from various phylogenetic lineages by matrixassisted laser desorption ionization-time of flight mass spectrometry. J. Clin. Microbiol. 47:2284-2287.

Marklein, G., M. Josten, U. Klanke, E. Muller, R. Horre, T. Maier, T. Wenzel, M. Kostrzewa, G. Bierbaum, A. Hoerauf, and H. G. Sahl. 2009. Matrix-assisted laser desorption ionization-time of flight mass spectrometry for fast and reliable identification of clinical yeast isolates. J. Clin. Microbiol. 47:2912-2917. 
Mellmann, A., F. Bimet, C. Bizet, A. D. Borovskaya, R. R. Drake, U. Eigner, A. M. Fahr, Y. He, E. N. Ilina, M. Kostrzewa, T. Maier, L. Mancinelli, W. Moussaoui, G. Prevost, L. Putignani, C. L. Seachord, Y. W. Tang, and D. Harmsen. 2009. High interlaboratory reproducibility of matrix-assisted laser desorption ionization-time of flight mass spectrometry-based species identification of nonfermenting bacteria. J. Clin. Microbiol. 47:3732-3734.

Mellmann, A., J. Cloud, T. Maier, U. Keckevoet, I. Ramminger, P. Iwen, J. Dunn, G. Hall, D. Wilson, P. Lasala, M. Kostrzewa, and D. Harmsen. 2008. Evaluation of matrix-assisted laser desorption ionization-time-of-flight mass spectrometry in comparison to $16 \mathrm{~S}$ rRNA gene sequencing for species identification of nonfermenting bacteria. J. Clin. Microbiol. 46:1946-1954.

Mlynarczyk, G., M. Kochman, M. Lawrynowicz, P. Fordymacki, A. Mlynarczyk, and J. Jeljaszewicz. 1998. Coagulase-negative variants of methicillin-resistant Staphylococcus aureus ssp. aureus strains isolated from hospital specimens. Zentralbl. Bakteriol. 288:373-381.

Nagy, E., T. Maier, E. Urban, G. Terhes, and M. Kostrzewa. 2009. Species identification of clinical isolates of Bacteroides by matrixassisted laser-desorption/ionization time-of-flight mass spectrometry. Clin. Microbiol. Infect. 15:796-802.

NMC. 1999. Current Concepts of Bovine Mastitis. 4th ed. NMC Inc., Madison, WI.

Odierno, L., L. Calvinho, P. Traverssa, M. Lasagno, C. Bogni, and E. Reinoso. 2006. Conventional identification of Streptococcus uberis isolated from bovine mastitis in Argentinean dairy herds. J. Dairy Sci. $89: 3886-3890$.

Peeler, E. J., M. J. Green, J. L. Fitzpatrick, and L. E. Green. 2003. The association between quarter somatic-cell counts and clinical mastitis in three British dairy herds. Prev. Vet. Med. 59:169-180.
Relman, D. A., J. S. Loutit, T. M. Schmidt, S. Falkow, and L. S. Tompkins. 1990. The agent of bacillary angiomatosis. An approach to the identification of uncultured pathogens. N. Engl. J. Med. 323:1573-1580.

Relman, D. A., T. M. Schmidt, R. P. MacDermott, and S. Falkow. 1992. Identification of the uncultured bacillus of Whipple's disease. N. Engl. J. Med. 327:293-301.

Ryzhov, V., and C. Fenselau. 2001. Characterization of the protein subset desorbed by MALDI from whole bacterial cells. Anal. Chem. 73:746-750.

Santos, J. E. P., R. L. A. Cerri, M. A. Ballou, G. E. Higginbotham, and J. H. Kirk. 2004. Effect of timing of first clinical mastitis occurrence on lactational and reproductive performance of Holstein dairy cows. Anim. Reprod. Sci. 80:31-45.

Sauer, S., A. Freiwald, T. Maier, M. Kube, R. Reinhardt, M. Kostrzewa, and K. Geider. 2008. Classification and identification of bacteria by mass spectrometry and computational analysis. PLoS ONE 3:e2843.

Seibold, E., T. Maier, M. Kostrzewa, E. Zeman, and W. Splettstoesser. 2010. Identification of Francisella tularensis by whole-cell matrixassisted laser desorption ionization-time of flight mass spectrometry: Fast, reliable, robust, and cost-effective differentiation on species and subspecies levels. J. Clin. Microbiol. 48:1061-1069.

Souto, L. I., C. Y. Minagawa, E. O. Telles, M. A. Garbuglio, M Amaku, P. A. Melville, R. A. Dias, S. T. Sakata, and N. R. Benites. 2010. Correlation between mastitis occurrence and the count of microorganisms in bulk raw milk of bovine dairy herds in four selective culture media. J. Dairy Res. 77:63-70. 